\title{
NORTH ATLANTIC TROPICAL CYCLONES AND U.S. FLOODING
}

\author{
by Gabriele Villarini, Radoslaw Goska, James A. Smith, and Gabriel A. Vecchi
}

\author{
North Atlantic tropical cyclones are responsible for major flooding \\ over large areas of the continental United States.
}

0 ver the past few years, we have been witnessing growing media coverage for inland flooding associated with North Atlantic tropical cyclones (TCs), with Hurricanes Irene (2011), Isaac (2012), and Sandy (2012) representing the "poster children" of this heightened interest. Flooding associated with landfalling TCs claims a large economic and societal toll, with several billion dollars in damage and numerous fatalities (e.g., Rappaport 2000; Pielke et al. 2008; Changnon 2008; Czajkowski et al. 2013; Jonkman et al. 2009; Mendelsohn et al. 2012; Peduzzi et al. 2012). As summarized by an article in the New York Times ("Storm's push north leaves punishing inland flooding,"

AfFILIATIONS: VILLARINI AND GOSKA-IIHR-Hydroscience \& Engineering, The University of lowa, lowa City, lowa; SMITHDepartment of Civil and Environmental Engineering, Princeton University, Princeton, New Jersey; VECCHI-Geophysical Fluid Dynamics Laboratory, National Oceanic and Atmospheric Administration, Princeton, New Jersey

CORRESPONDING AUTHOR: Gabriele Villarini, IIHRHydroscience and Engineering, The University of lowa, 306 C. Maxwell Stanley Hydraulics Laboratory, lowa City, IA 52242 E-mail: gabriele-villarini@uiowa.edu

The abstract for this article can be found in this issue, following the table of contents.

DOI:10.1175/BAMS-D-13-00060.1

A supplement to this article is available online (10.1175/BAMS-D-13-00060.2)

In final form 10 January 2014

C2014 American Meteorological Society
30 August 2011) about Hurricane Irene (2011), "While most eyes warily watched the shoreline during Hurricane Irene's grinding ride up the East Coast, it was inland-sometimes hundreds of miles inland-where the most serious damage actually occurred. And the major culprit was not wind, but water." In fact, flooding does not only impact the coastal regions close to the point of landfall, but also affects large areas away from the coast, and often hundreds of kilometers away from the center of the storm (e.g., Villarini et al. 2011). Despite these large societal and economic repercussions, there is limited published literature about inland flooding from TCs, in contrast to the attention that has been paid in monitoring and improving the understanding of coastal damage caused by storm surge and wind (e.g., Elsberry 2002; U.S. Department of Commerce 2011; Zandbergen 2009).

While various studies have examined heavy rainfall associated with North Atlantic TCs (e.g., Groisman et al. 2004; Larson et al. 2005; Shepherd et al. 2007; Knight and Davis 2009; Konrad and Perry 2010; Kunkel et al. 2010; Barlow 2011), the little attention that inland TC flooding has received has generally focused on case studies of specific events or over a specific area (e.g., Sturdevant-Rees et al. 2001; Smith et al. 2011; Villarini et al. 2011; Villarini and Smith 2010, 2013). Heavy rainfall is an important ingredient in flood generation, yet it is insufficient to allow direct inference of flooding because of the crucial role of localized differences in land use/land cover and antecedent soil moisture conditions in 
flooding (e.g., Hellin et al. 1999; Sturdevant-Rees et al. 2001). In this study we produce a climatology of flooding associated with North Atlantic TCs, highlighting the regions of the United States for which these storms are important flood agents. The focus will be on all the TCs making landfall in the United States from 1981 to 2011, and the methodology will leverage on U.S. Geological Survey (USGS) discharge measurements to provide a data-driven climatological view of flooding associated with these catastrophic events.

Moreover, while there is a growing literature examining the relationship between TC frequency and large-scale climate predictors (e.g., Elsner et al. 2000; Camargo et al. 2007; Latif et al. 2007; Vimont and Kossin 2007; Vecchi and Soden 2007; Tippett et al. 2011; Villarini et al. 2010, 2012), the nexus between magnitude and frequency of flooding associated with TCs and climate controls is still unexplored. Here we will examine the controls exerted by the North Atlantic Oscillation (NAO) and El Niño-Southern Oscillation (ENSO) on TC flood magnitude and frequency because of their link with U.S. landfalling TCs (e.g., Bove et al. 1998; Elsner et al. 2000, 2004; Elsner 2003; Pielke 2009; Kossin et al. 2010; Colbert and Soden 2012; Villarini et al. 2012).

METHODOLOGY. We examine U.S. flooding associated with landfalling TCs over the period 1981-2011 using the discharge measurements from 3090 USGS stream gage stations (consult supplementary Fig. ES1 online at http://dx.doi.org/ /0.II75/BAMS -D-13-00060.2 for their location and data availability). We define as the flooding associated with a TC the largest flood peak measured by a stream gage station located within $500 \mathrm{~km}$ from the center of the storm during a time window of two days prior to and seven days after the passage of a storm (e.g., Hart and Evans 2001; Kunkel et al. 2010; Barlow 2011; Villarini and Smith 2010, 2013). At each stream gage station, we then compute the 10-yr flood peak, which represents the flood peak that is expected to occur, on average, once every 10 years and corresponds to the 90 th percentile of the flood peak distribution. We focus on stations with at least 20 annual maximum flood peaks over the period 1981-2011 (they represent the largest flood peak in a given year) and compute the 90 th percentile of the flood peak distribution at each location. The 10 -yr flood peaks are computed only over the past 31 years to mitigate potential effects due to anthropogenic modifications of these catchments (e.g., construction of dams, changes in land use/land cover; e.g., Villarini and Smith 2010, 2013).

Because of the strong link between discharge and drainage area (i.e., watersheds with larger drainage

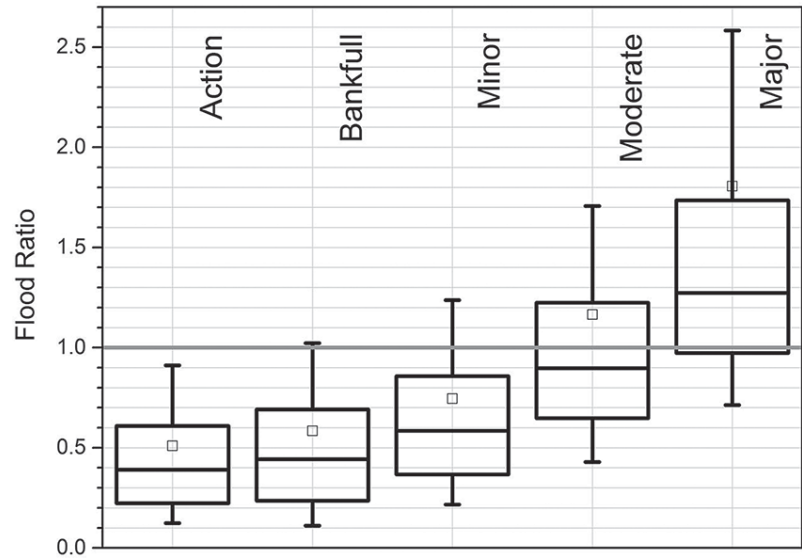

FIG. I. Relationship between the values of the flood ratios and NWS high water terms. The whiskers represent the 10 th and the 90 th percentiles, the limits of the boxes the 25 th and 75 th percentiles, and the horizontal line and square inside the boxes the median and mean, respectively.

area will tend to have larger discharge values; e.g., Gupta et al. 1994), we need to normalize the TC flood peaks by their 10 -yr flood peak to be able to provide a regional view. This flood ratio provides information about how much larger than the 10 -yr flood peak the TC flood was: values larger (smaller) than 1 indicate that flood peaks caused by a given TC are larger (smaller) than the 10-yr flood peak. Recently, Rowe and Villarini (2013) used this approach to characterize flooding associated with six predecessor rain events over the central United States.

To place the flood ratio values in context, we use the high water level terminology of the National Weather Service (NWS). There are three main high water terms used by NWS: "action," "bankfull," and "flood." The flood term is further divided into minor, moderate, and major. A definition of each of these terms is provided by NWS (2012). For a given stream gage station, we can compute the flood ratio value corresponding to each of the NWS high water terms. We can do this for all of the 3090 USGS stations for which a NWS classification is in place, and plot the distribution of the flood ratio values corresponding to each category (Fig. 1). By using the median as reference point, flood ratios between 0.5 and 0.6 refer to bankfull conditions (the distribution and values for the action level are similar but slightly smaller), with values larger than 0.6 referring to flooding. Between 0.6 and 1 , the flood ratio generally indicates minor to moderate flooding, with values in excess of 1-1.3 pointing to major flooding. Keeping in mind the variability within each category, these results are helpful in interpreting the values of the 


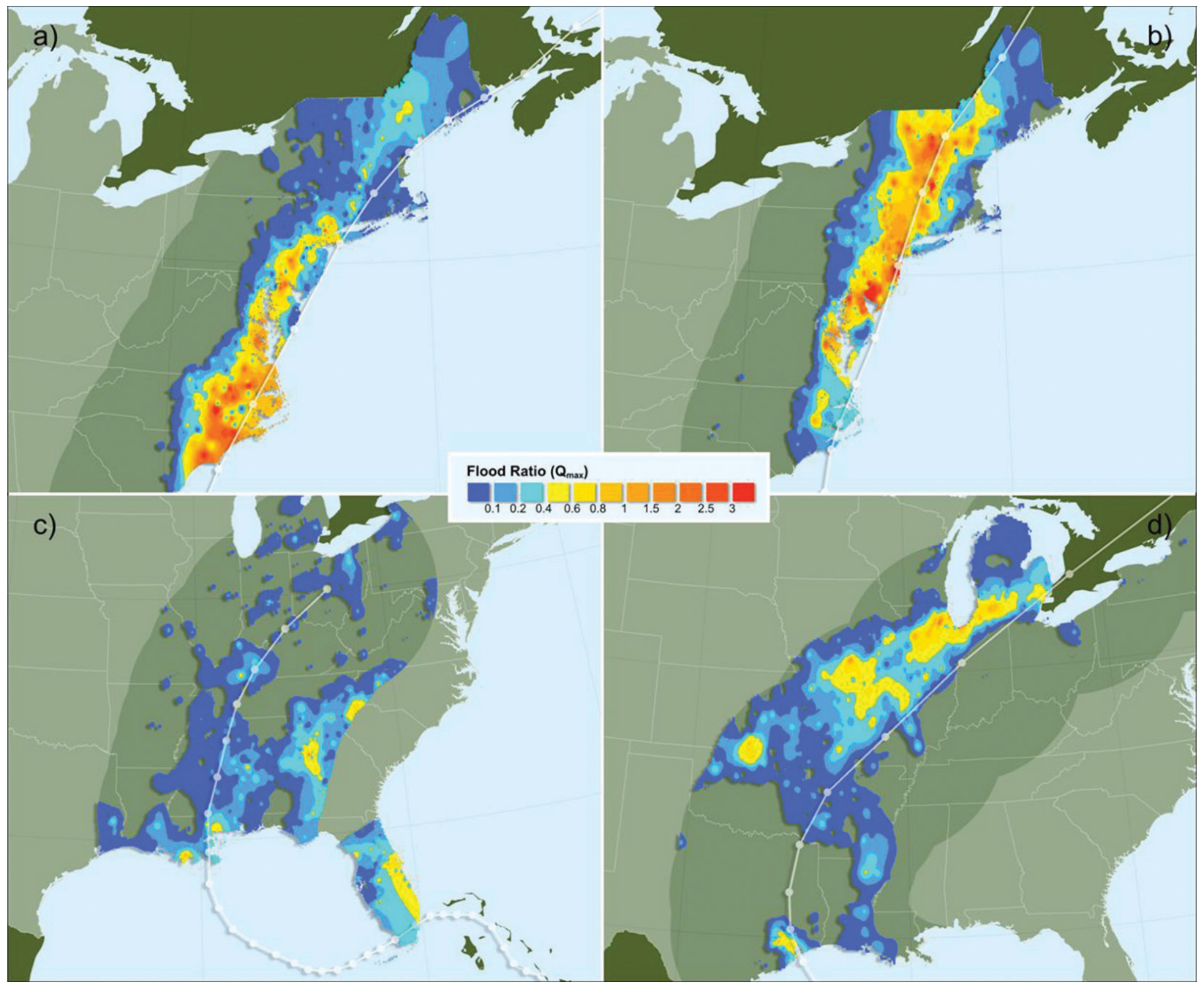

FIG. 2. Flood ratio maps for (a) Hurricane Floyd (1999), (b) Hurricane Irene (20II), (c) Hurricane Katrina (2005), and (d) Hurricane Ike (2008). Values larger (smaller) than I indicate TC flood peaks larger (smaller) than the 10-yr flood peak at a particular location (see Fig. I for NWS high water classification). Each storm track is displayed in white [from the North Atlantic Hurricane Database (HURDAT)]. The darker shades of green represent the $500-\mathrm{km}$ buffer around the center of circulation.

flood ratio associated with TC flooding in terms of impacts.

The examination of the relationship between TC flooding and large-scale climate indices is based on the stratification of the study period into different groups of years according to the value of the NAO and ENSO. To examine the connection with NAO, we have focused on positive and negative phases, depending on the sign of the NAO anomalies averaged over the May-June period (e.g., Elsner 2003; Kossin et al. 2010; Villarini et al. 2012). Regarding ENSO, the selection is based on the classification of positive/ neutral/negative phase according to the NWS Climate Prediction Center (www.cpc.ncep.noaa.gov/products /analysis_monitoring/ensostuff/ensoyears.shtml) for August-October. Table ES1 provides a summary of the years classified according to values of the associated state of ENSO and the NAO.

RESULTS. Over the period 1981-2011, over 100 TCs affected the United States, with the eastern seaboard and Florida being the areas that were the most affected (Fig. ES1). For each of these storms, we have created flood ratio maps by interpolating the values among the different stream gage stations using the inverse distance weighting method. Figure 2 shows the spatial extent of flooding associated with two hurricanes making landfall along the U.S. East Coast [Hurricanes Floyd (1999) and Irene (2011)] and two hurricanes making landfall in the Gulf of Mexico [Katrina (2005) and Ike (2008)]. There are large areas in the path of these storms with flood ratios larger than 2 : 


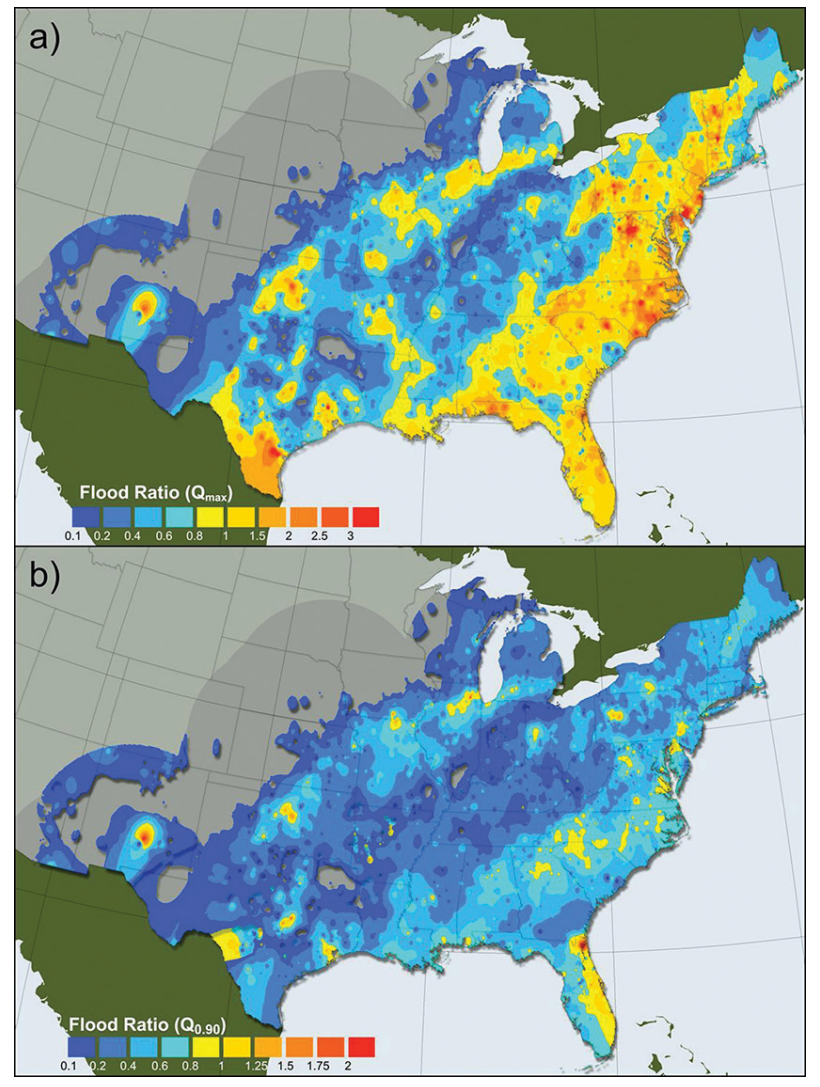

FIG. 3. Spatial interpolation of the (a) maximum and (b) 90 th percentile of the flood ratio values associated with TCs at each location. The darker shades of gray represent the extent of the $500-\mathrm{km}$ buffer around the center of circulation for all the storms during the study period. Note that the color bar in the two panels spans over different ranges.

these hurricanes caused flood peaks that were more than twice as large as the corresponding 10 -yr flood peak, and that would be generally classified as major flooding according to the NWS classification (Fig. 1). Some of the largest flood ratios over the past 30 years are associated with Hurricane Irene, with flood ratio values larger than 3. Maps of this kind provide key information necessary to highlight the prevalence of TC-related flooding away from the coast. Moreover, as is shown by creating the flood ratio maps for the recent Hurricanes Isaac (2012) and Sandy (2012) (Fig. ES2), it is also possible to create the flood ratio maps shortly after the TC landfall, providing valuable information for a more targeted recovery effort by the emergency services, and a first-order assessment of the inland areas that may suffer from major damage.

By examining all the flood peaks associated with landfalling TCs over the past 31 years, we are able to provide a climatological view of the areas of the United States that have been most affected by these catastrophic events, as summarized in Fig. 3. There are large areas of the study region with flood peak values exceeding the 10-yr flood peaks. Most of the largest flood ratio values are located along the eastern seaboard, from North Carolina to Vermont. The Appalachian Mountains represent a natural divide, shielding the western part of the domain. Other areas with flood ratios larger than 1 are the coastal regions, in particular from coastal Louisiana to Florida. We also observe a local minimum in Georgia, consistent with results related to the climatology of heavy rainfall associated with landfalling TCs (e.g., Hart and Evans 2001; Kunkel et al. 2010; Villarini and Smith 2010; Barlow 2011). These conclusions hold regardless of whether we examine the largest TC flood ratio (Fig. 3a) or the 90th percentiles of the flood ratios (Fig. 3b), indicating that these features are not related to a single event but are more persistent.

It is clear in Fig. 3 that TCs are an important flood agent not only for the eastern United States, but also for large areas of the central United States. This secondary swath is generally associated with storms making landfall along the Gulf of Mexico and then moving northward over the U.S. Midwest. While the magnitude of these flood peaks is not as large as over the eastern United States, TCs can still cause major flooding. Notably, areas that have been impacted include major U.S. Midwest cities, such as St. Louis, Kansas City, Chicago, and Detroit. These results differ from what one may have inferred from previous analyses that were focused on heavy rainfall associated with TCs (e.g., Kunkel et al. 2010; Barlow 2011), as these regions did not stand out as substantially affected by heavy rainfall from TCs. These differences highlight the role of land use/land cover properties and antecedent soil moisture conditions to flooding.

After having characterized the role of North Atlantic TCs as flood agents over the United States, we examine whether there is a relationship between the number and magnitude of TC floods and largescale climate indices, more specifically NAO and ENSO. Let us start with the NAO (Fig. 4). Most of the TC flood peaks tend to occur during the negative phase of the NAO, in particular over the areas west of the Appalachian Mountains (Figs. 4e,f). These results are consistent with the role played by the NAO in steering these storms (e.g., Elsner 2003; Elsner et al. 2000; Kossin et al. 2010; Colbert and Soden 2012). During the negative phase of the NAO, the Bermuda high tends to shift more toward the eastern Atlantic Ocean, with a larger number of TCs making landfall along the U.S. coast (e.g., Elsner 2003; Villarini et al. 2012). Kossin et al. (2010) found a reduction in the 
expected number of TCs for increasing NAO values. The phase of the NAO is related not only to the frequency of TC floods, but also to their magnitudes. As shown in Figs. 4a-d, the largest TC flood peaks tend to occur during the negative phase of the NAO, with flood ratio values in excess of 1 over most of the study region. These results suggest that the largest threat posed by North Atlantic TCs in terms of flooding is generally during the negative phase of the NAO.

Figure 5 summarizes the analyses for ENSO. Most of the TC flood peaks over the central part of the study region tend to occur during the neutral phase of the ENSO (Fig. 5h), with a regionally widespread influence during the negative phase (Fig. 5i), in particular in the western part of the domain. This is generally consistent with Elsner (2003), who found that during La Niña years there is a larger probability of straight moving storms making landfall along the Gulf Coast. On the contrary, the link between TCs and floods during El Niño tends to be more restricted to the U.S. East Coast. These results are similar to Kossin et al. (2010), who found that the annual rate of occurrence for TCs in their cluster 1 (they tend to form off of the U.S. East Coast and into the central North Atlantic, with a marked northward component in their tracks) increases for increasing values of the Southern Oscillation index (SOI), with a decrease for the other three clusters with increasing SOI values.

Large TC flood peaks along the U.S. East Coast can occur during any ENSO phase, even though they are more limited to the northeastern United States during La Niña years (Fig. 5c). Over the central United States, the largest flood peaks tend to occur during the neutral and negative ENSO phases (Figs. 5b,c,h,i), with limited activity during El Niño years (Figs. 5a,g). These results indicate that ENSO is not only an important predictor of North Atlantic TC activity, but it also plays a role in the tracking of these storms.

CONCLUSIONS AND DISCUSSION. This study focused on flooding over the continental United States associated with North Atlantic TCs during the period 1981-2011. Analyses were based on USGS discharge measurements and provided a characterization of the U.S. regions that are more affected by this natural hazard. Our findings indicate that TCs are responsible for large flooding over the eastern United States, from Florida to Vermont and Maine. Moreover, there is a secondary swath of enhanced TC flooding over the central United States, as far north and west as Illinois, Wisconsin, and Michigan. Overall, the results of this study highlight a broad impact of TCs through

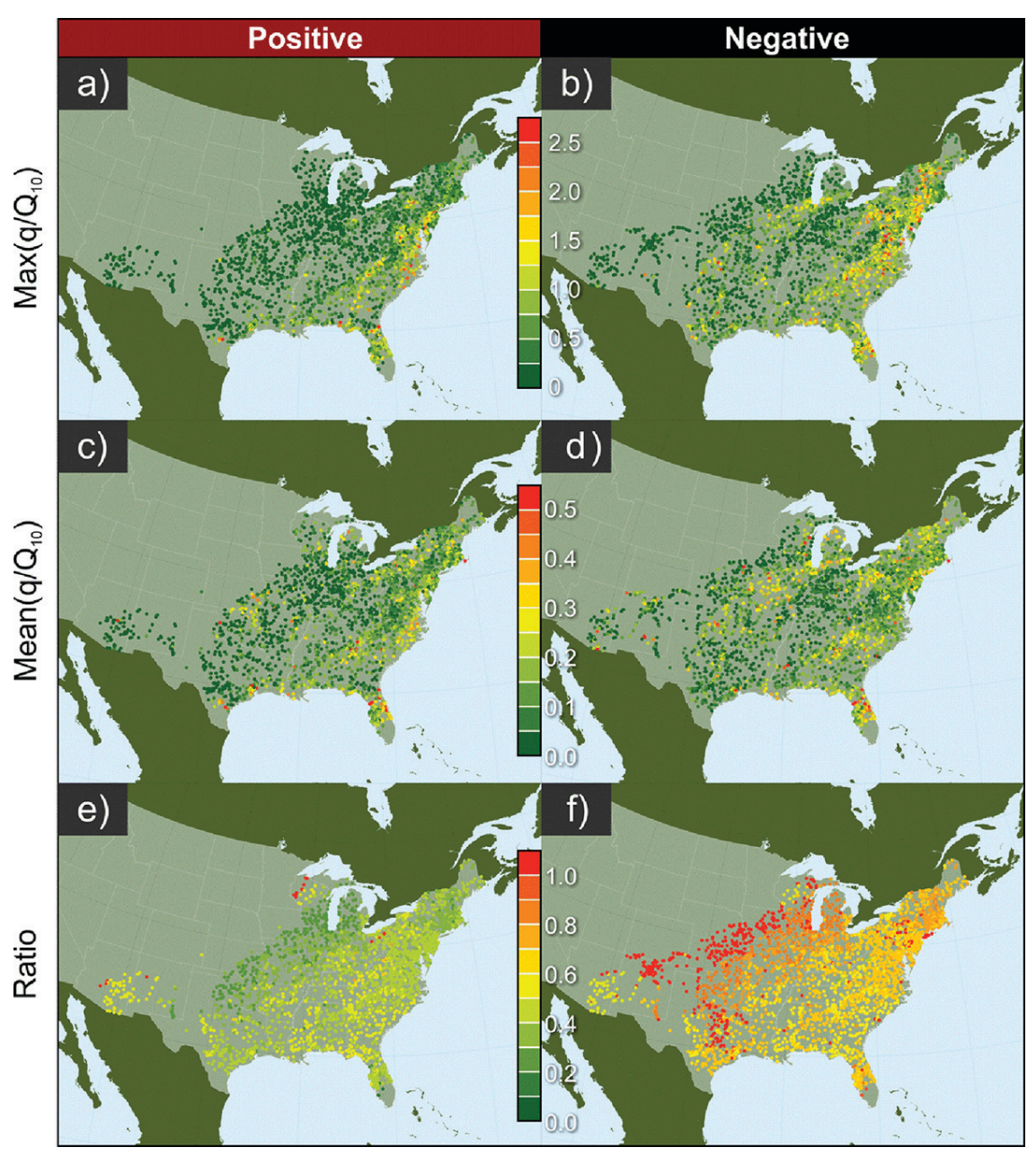

FIG. 4. Examination of the dependence of TC flood number and magnitude on the (left) positive and (right) negative phase of the NAO (consult Table ESI in the supplemental material for a list of years in each phase). Shown are the (a),(b) largest and (c),(d) mean flood ratio values during each NAO phase, and (e),(f) the proportion of TC flood peaks with respect to the total number of TC flooding occurring during the two NAO phases. 


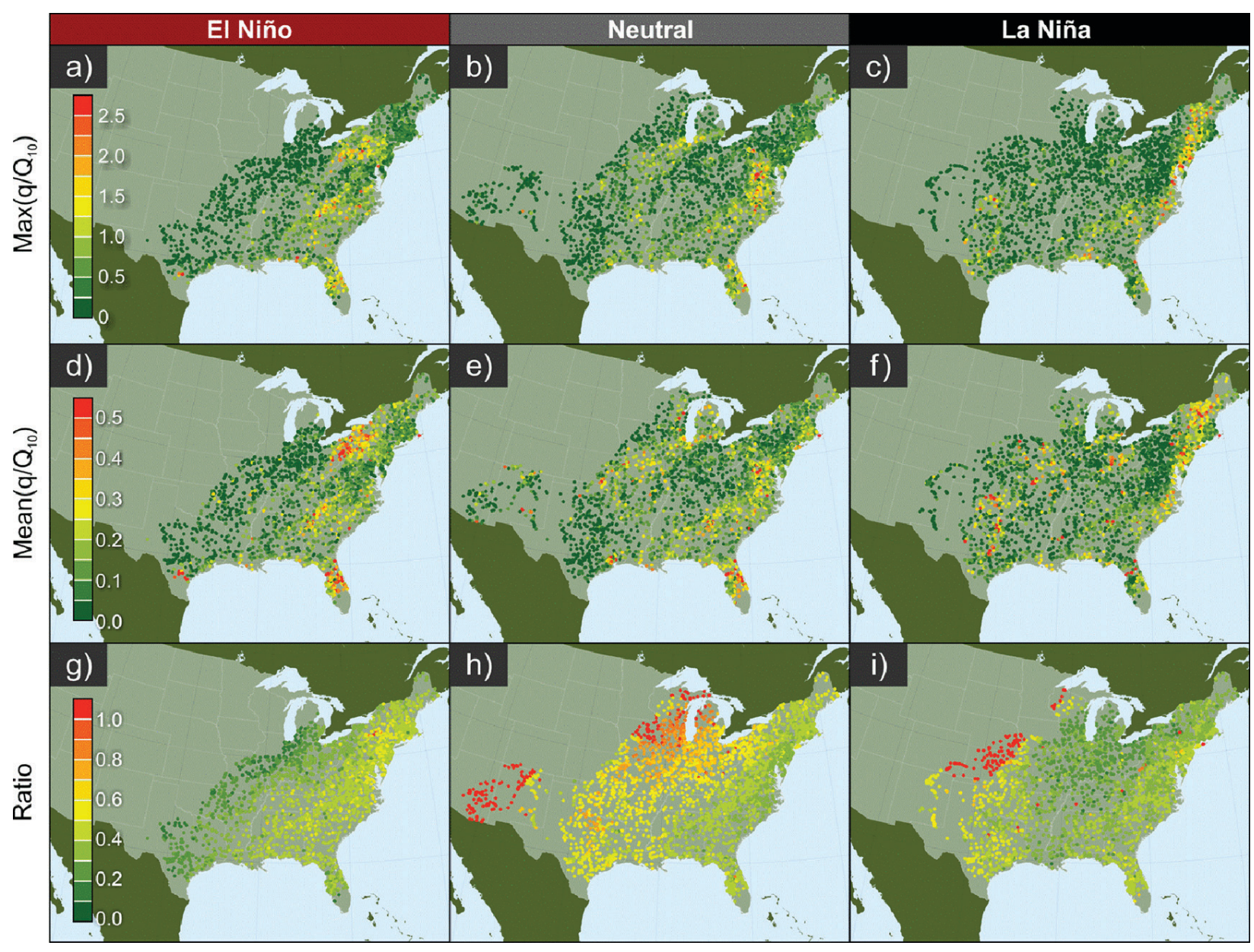

FIG. 5. Examination of the dependence of TC flood number and magnitude on the (left) EI Niño, (middle) neutral, and (right) La Niña phase of the ENSO (consult Table ESI for a list of years in each phase). Shown are the (a)-(c) largest and (d)-(f) mean flood ratio values during each ENSO phase, and (g)-(i) the proportion of TC flood peaks with respect to the total number of TC flooding occurring during the three ENSO phases.

inland flooding. This is in contrast with storm surge and wind damage arising from TCs, which are rather localized phenomena affecting limited areas that are concentrated near the landfall location.

Examination of the relationship between TC flooding and large-scale climate indices uncovered the role played by NAO and ENSO. Most of the TC flood peaks tend to occur during the negative phase of the NAO, which is also associated with some of the largest flood peak magnitudes. Depending on the phase of ENSO, different areas of the study region are more affected. During El Niño years, the U.S. East Coast is affected more than during neutral or La Niña years, in which the center of action shifts toward the central United States. While previous studies have examined the role of ENSO in the genesis and development of North Atlantic TCs, these results support the notion that ENSO plays also a role in the tracking of these storms, as recently discussed in Kossin et al. (2010). Although we have not explored the relationship of the different "flavors" of ENSO (e.g., "Dateline" versus conventional El Niño events) on flood statistics, subsequent analysis should focus on the potential for distinct impacts given the different teleconnections associated with each type of ENSO (e.g., Larkin and Harrison 2005; Kim et al. 2009) These relationships between TC flooding and NAO and ENSO can provide basic information related to the areas of the United States that are more at risk from flooding associated with North Atlantic TCs depending on the values of these indices. Future work should explore the mechanisms behind, and the potential for extended range prediction arising from, these relationships between inland TC-flooding and large-scale atmospheric and oceanic conditions.

The results of this study represent a key step toward a better understanding and characterization of flooding associated with North Atlantic TCs, yet they also 
highlight gaps in our understanding. As even the basic climatology of inland TC flooding had been previously uncharacterized, the character of past and possible future variations of this hazard remains unexplored, as do possible connections between it and climate variation and change. Understanding these potential climate connections takes on particular importance given both the broad footprint of TC-related inland freshwater flooding and the strong consensus among modeling studies for an increase in TC rainfall over the coming century (e.g., Knutson et al. 2010, 2013). Because the inland impacts are much larger than previously thought based on rainfall analyses, they indicate that for large areas of the United States awareness about this flood hazard should potentially be increased.

ACKNOWLEDGMENTS. The first two authors acknowledge funding by the Iowa Flood Center, IIHRHydroscience \& Engineering. Gabriele Villarini also acknowledges financial support from the USACE Institute for Water Resources. James Smith acknowledges financial support from the Willis Research Network and NOAA Cooperative Institute for Climate Sciences.

\section{REFERENCES}

Barlow, M., 2011: Influence of hurricane-related activity on North American extreme precipitation. Geophys. Res. Lett., 38, L04705, doi:10.1029/2010GL046258.

Bove, M. C., J. B. Elsner, C. W. Landsea, X. Niu, and J. J. O’Brien, 1998: Effect of El Niño on U.S. landfalling hurricanes, revisited. Bull. Amer. Meteor. Soc., 79, 2477-2482, doi:10.1175/1520-0477(1998)0792.0.CO;2.

Camargo, S. J., K. A. Emanuel, and A. H. Sobel, 2007: Use of a genesis potential index to diagnose ENSO effects on tropical cyclone genesis. J. Climate, 20, 4819-4834, doi:10.1175/JCLI4282.1.

Changnon, S. A., 2008: Assessment of flood losses in the U.S. J. Contemp. Water Res. Educ., 138, 38-44, doi:10.1111/j.1936-704X.2008.00007.x.

Colbert, A. J., and B. J. Soden, 2012: Climatological variations in North Atlantic tropical cyclone tracks. J. Climate, 25, 657-673, doi:10.1175/JCLI -D-11-00034.1.

Czajkowski, J., G. Villarini, E. Michel-Kerjan, and J. A. Smith, 2013: Determining tropical cyclone inland flooding loss on a large scale through a new flood peak ratio-based methodology. Environ. Res. Lett., 8, 044056, doi:10.1088/1748-9326/8/4/044056.

Elsberry, R., 2002: Predicting hurricane landfall precipitation: Optimistic and pessimistic views from the Symposium on Precipitation Extremes. Bull. Amer. Meteor. Soc., 83, 1333-1339.
Elsner, J. B., 2003: Tracking hurricanes. Bull. Amer. Meteor. Soc., 84, 353-356, doi:10.1175/BAMS-84-3-353.

— , K. B. Liu, and B. Kocker, 2000: Spatial variations in major U.S. hurricane activity: Statistics and a physical mechanism. J. Climate, 13, 2293-2305, doi:10.1175/1520-0442(2000)0132.0.CO;2.

—, X. Niu, and T. H. Jagger, 2004: Detecting shifts in hurricane rates using a Markov chain Monte Carlo approach. J. Climate, 17, 2652-2666, doi:10.1175/1520-0442(2004)017<2652:DSIHRU>2 $.0 . \mathrm{CO} ; 2$.

Groisman, P. Ya., R. W. Knight, T. R. Karl, D. R. Easterling, B. Sun, and J. H. Lawrimore, 2004: Contemporary changes of the hydrological cycle over the contiguous United States: Trends derived from in situ observations. J. Hydrometeor., 5, 64-85, doi:10.1175/1525-7541(2004)0052.0.CO;2.

Gupta, V. K., O. J. Mesa, and D. R. Dawdy, 1994: Multiscaling theory of flood peaks: Regional quantile analysis. Water Resour. Res., 30 (12), 3405-3421, doi:10.1029/94WR01791.

Hart, R. E., and J. L. Evans, 2001: A climatology of the extratropical transition of Atlantic tropical cyclones. J. Climate, 14, 546-564, doi:10.1175/1520 -0442(2001)0142.0.CO;2.

Hellin, J., M. Haigh, and F. Marks, 1999: Rainfall characteristics of Hurricane Mitch. Nature, 399, 316, doi:10.1038/20577.

Jonkman, S. N., B. Maaskant, E. Boyd, and M. L. Levitan, 2009: Loss of life caused by the flooding of New Orleans after Hurricane Katrina: Analysis of the relationship between flood characteristics and mortality. Risk Anal., 29 (5), 676-698, doi:10.1111/j.1539 $-6924.2008 .01190 . x$.

Kim, H.-M., P. J. Webster, and J. A. Curry, 2009: Impact of shifting patterns of Pacific Ocean warming on North Atlantic tropical cyclones. Science, 325, 77-80, doi:10.1126/science.1174062.

Knight, D. B., and R. E. Davis, 2009: Contribution of tropical cyclones to extreme rainfall events in the southeastern United States. J. Geophys. Res., 114, D23102, doi:10.1029/2009JD012511.

Knutson, T. R., and Coauthors, 2010: Tropical cyclones and climate change. Nat. Geosci., 3, 157-163, doi:10.1038/ngeo779.

_ , and Coauthors, 2013: Dynamical downscaling projections of twenty-first-century Atlantic hurricane activity: CMIP3 and CMIP5 model-based scenarios. J. Climate, 26, 6591-6617, doi:10.1175 /JCLI-D-12-00539.1.

Konrad, C. E., and L. B. Perry, 2010: Relationships between tropical cyclones and heavy rainfall in the Carolina region of the USA. Int. J. Climatol., 30, 522-534. 
Kossin, J. P., S. J. Camargo, and M. Sitkowski, 2010: Climate modulation of North Atlantic hurricane tracks. J. Climate, 23, 3057-3076, doi:10.1175/2010JCLI3497.1.

Kunkel, K. E., D. R. Easterling, D. A. R. Kristovich, B. Gleason, L. Stoecker, and R. Smith, 2010: Recent increases in U.S. heavy precipitation associated with tropical cyclones. Geophys. Res. Lett., 37, L24706, doi:10.1029/2010GL045164.

Larkin, N. K., and D. E. Harrison, 2005: On the definition of El Niño and associated seasonal average U.S. weather anomalies. Geophys. Res. Lett., 32, L13705, doi:10.1029/2005GL022738.

Larson, J., Y. Zhou, and R. W. Higgins, 2005: Characteristics of landfalling tropical cyclones in the United States and Mexico: Climatology and interannual variability. J. Climate, 18, 1247-1262, doi:10.1175/ JCLI3317.1.

Latif, M., N. Keenlyside, and J. Bader, 2007: Tropical sea surface temperature, vertical wind shear, and hurricane development. Geophys. Res. Lett., 34, L01710, doi:10.1029/2006GL027969.

Mendelsohn, R., K. Emanuel, S. Chonabayashi, and L. Bakkensen, 2012: The impact of climate change on global tropical cyclone damage. Nat. Climate Change, 2, 205-209, doi:10.1038/nclimate1357.

National Weather Service, 2012: Definitions and general terminology. National Weather Service Manual 10950, Operations and Services, Hydrologic Services Program, NWSPD 10-9, 5 pp. [Available online at www.nws.noaa.gov/directives/sym/pd01009050curr. pdf.]

Peduzzi, P., B. Chatenoux, H. Dao, A. De Bono, C. Herold, J. Kossin, F. Mouton, and O. Nordbeck, 2012: Global trends in tropical cyclone risk. Nat. Climate Change, 2, 289-294, doi:10.1038/nclimate1410.

Pielke, R. A., 2009: United States hurricane landfalls and damages: Can one- to five-year predictions beat climatology? Environ. Hazards, 8, 187-200, doi:10.3763 /ehaz.2009.0017.

- , J. Gratz, C. W. Landsea, D. Collins, M. A. Saunders, and R. Musulin, 2008: Normalized hurricane damage in the United States: 1900-2005. Nat. Hazards Rev., 9 (1), 29-42, doi:10.1061/(ASCE)1527 -6988(2008)9:1(29).

Rappaport, E. N., 2000: Loss of life in the United States associated with recent Atlantic tropical cyclones. Bull. Amer. Meteor. Soc., 81, 2065-2073, doi:10.1175/1520-0477(2000)0812.3.CO;2.

Rowe, S. T., and G. Villarini, 2013: Flooding associated with predecessor rain events over the Midwest United States. Environ. Res. Lett., 8, 024007, doi:10.1088 /1748-9326/8/2/024007.
Shepherd, J. M., A. Grundstein, and T. L. Mote, 2007: Quantifying the contribution of tropical cyclones to extreme rainfall along the coastal southeastern United States. Geophys. Res. Lett., 34, L23810, doi:10.1029/2007GL031694.

Smith, J. A., G. Villarini, and M. L. Baeck, 2011: Mixture distributions and the climatology of extreme rainfall and flooding in the eastern United States. J. Hydrometeor., 12, 294-309, doi:10.1175 /2010JHM1242.1.

Sturdevant-Rees, P. L., J. A. Smith, J. Morrison, and M. L. Baeck, 2001: Tropical storms and the flood hydrology of the central Appalachians. Water Resour. Res., 37 (8), 2143-2168, doi:10.1029/2000WR900310.

Tippett, M. K., S. J. Camargo, and A. H. Sobel, 2011: A Poisson regression index for tropical cyclone genesis and the role of large-scale vorticity in genesis. $J$. Climate, 24, 2335-2357, doi:10.1175/2010JCLI3811.1.

U.S. Department of Commerce, Service Assessment Hurricane Irene, August 21-30,2011.129 pp. [Available online at www.nws.noaa.gov/om/assessments/pdfs /Irene2012.pdf.]

Vecchi, G. A., and B. J. Soden, 2007: Effect of remote sea surface temperature change on tropical cyclone potential intensity. Nature, 450, 1066-1070, doi:10.1038/nature06423.

Villarini, G., and J. A. Smith, 2010: Flood peak distributions for the eastern United States. Water Resour. Res., 46, W06504, doi:10.1029/2009WR008395.

— , and _ 2013: Flooding in Texas: Examination of temporal changes and impacts of tropical cyclones. J. Amer. Water Resour. Assoc., 49 (4), 825-837, doi:10.1111/jawr.12042.

—, G. A. Vecchi, and J. A. Smith, 2010: Modeling of the dependence of tropical storm counts in the North Atlantic basin on climate indices. Mon. Wea. Rev., 138, 2681-2705, doi:10.1175/2010MWR3315.1.

—, J. A. Smith, M. L. Baeck, T. Marchok, and G. A. Vecchi, 2011: Characterization of rainfall distribution and flooding associated with U.S. landfalling tropical cyclones: Analyses of Hurricanes Frances, Ivan, and Jeanne (2004). J. Geophys. Res., 116, D23116, doi:10.1029/2011JD016175.

—, G. A. Vecchi, and J. A. Smith, 2012: U.S. landfalling and North Atlantic hurricanes: Statistical modeling of their frequencies and ratios. Mon. Wea. Rev., 140, 44-65, doi:10.1175/MWR-D-11-00063.1.

Vimont, D. J., and J. P. Kossin, 2007: The Atlantic meridional mode and hurricane activity. Geophys. Res. Lett., 34, L07709, doi:10.1029/2007GL029683.

Zandbergen, P., 2009: Exposure of US counties to Atlantic tropical storms and hurricanes, 1851-2003. Nat. Hazards, 48, 83-99, doi:10.1007/s11069-008-9250-6. 